\title{
Effect of Dietary Supplementation with a Natural Extract of Sclerocarya birrea on Glycemic Metabolism in Subjects with Prediabetes: A Randomized Double-Blind Placebo-Controlled Study
}

\author{
Desirée Victoria-Montesinos ${ }^{1}\left(\mathbb{D}\right.$, Maravillas Sánchez-Macarro ${ }^{1}{ }^{(}$, José Antonio Gabaldón-Hernández ${ }^{1}(\mathbb{D}$, \\ María Salud Abellán-Ruiz ${ }^{1}$, María Querol-Calderón ${ }^{1}$, Antonio J. Luque-Rubia ${ }^{1}$, Enrique Bernal-Morell ${ }^{2}{ }^{(1)}$, \\ Vicente Ávila-Gandía ${ }^{1}$ and Francisco Javier López-Román ${ }^{1,3, *(\mathbb{D}}$
}

1 Health Sciences Department, Campus de los Jerónimos, Universidad Católica San Antonio de Murcia (UCAM), Carretera de Guadalupe s/n, 30107 Murcia, Spain; dvictoria@ucam.edu (D.V.-M.); msanchez4@ucam.edu (M.S.-M.); jagabaldon@ucam.edu (J.A.G.-H.); msabellan@ucam.edu (M.S.A.-R.); mquerol@ucam.edu (M.Q.-C.); ajluque@ucam.edu (A.J.L.-R.); vavila@ucam.edu (V.Á.-G.)

2 Unit of Infectious Diseases, Hospital General Universitario Reina Sofía, 30003 Murcia, Spain; ebm.hgurs@gmail.com

check for

updates

Citation: Victoria-Montesinos, D.;

Sánchez-Macarro, M.;

Gabaldón-Hernández, J.A.;

Abellán-Ruiz, M.S.; Querol-Calderón,

M.; Luque-Rubia, A.J.; Bernal-Morell,

E.; Ávila-Gandía, V.; López-Román,

F.J. Effect of Dietary Supplementation with a Natural Extract of Sclerocarya

birrea on Glycemic Metabolism in

Subjects with Prediabetes: A

Randomized Double-Blind

Placebo-Controlled Study. Nutrients

2021, 13, 1948. https://doi.org/

10.3390/nu13061948

Academic Editor: J. Mark Brown

Received: 10 May 2021

Accepted: 4 June 2021

Published: 6 June 2021

Publisher's Note: MDPI stays neutral with regard to jurisdictional claims in published maps and institutional affiliations.

Copyright: (c) 2021 by the authors. Licensee MDPI, Basel, Switzerland. This article is an open access article distributed under the terms and conditions of the Creative Commons Attribution (CC BY) license (https:// creativecommons.org/licenses/by/ $4.0 /)$.
3 Primary Care Research Group, Biomedical Research Institute of Murcia (IMIB-Arrixaca), 30120 Murcia, Spain

* Correspondence: jlroman@ucam.edu; Tel.: +34-968278757

\begin{abstract}
A randomized, double-blind, placebo-controlled study was conducted with the primary objective of assessing the effect of a natural extract of Sclerocarya birrea on glucose metabolism in subjects with prediabetes. The duration of the study was 90 days. Thirty-three subjects assigned to the experimental group (daily ingestion of $100 \mathrm{mg}$ of the nutraceutical product) and 34 assigned to the placebo group completed the study. There were 36 men and 31 women with a mean age of $32.3 \pm 14.1$ years. In the area under the curve (AUC) of the oral glucose tolerance test (OGTT), statistically significant decreases in the experimental group at 40 and 90 days as compared with baseline were found, whereas significant changes in the placebo group were not observed. Withingroup differences were statistically significant in favor of the experimental group for glucose peak at OGTT, serum insulin, insulin resistance markers, and flow-mediated dilation. Changes in lipid and anthropometric parameters were not observed, although there was a trend for lower cholesterol levels and a decrease in body weight in the experimental group. Decreases in systolic blood pressure were also higher among subjects in the experimental group. This exploratory study confirms the antidiabetic activity of Sclerocarya birrea in prediabetes. Further studies using better measurements of beta-cell function are needed to clarify the underlying mechanisms of the hypoglycemic effect of this natural compound.
\end{abstract}

Keywords: prediabetes; Sclerocarya birrea; glucose metabolism; insulin resistance; lipid profile; nutraceutical product; clinical trial

\section{Introduction}

Prediabetes is an intermediate state of hyperglycemia with glycemic parameters above normal but below the diabetes threshold. The specific parameters included in the criteria for the definition of prediabetes are not uniform, with impaired glucose tolerance (IGT) of $140-199 \mathrm{mg} / \mathrm{dL}$ after ingestion of $75 \mathrm{~g}$ of oral glucose load, impaired fasting glucose (IFG) of 100 or 110 to $125 \mathrm{mg} / \mathrm{dL}$, and an additional criterion of hemoglobin A1c (HbA1c) at a level of $5.7 \%$ to $6.4 \%$ [1,2]. According to the American Diabetes Association (ADA), relying on one test may underestimate the prevalence of prediabetes [1].

Prediabetes is increasingly recognized as an important metabolic state, predisposing individuals to progression to overt type 2 diabetes ( $25 \%$ of subjects within $3-5$ years and 
as many as 70\% within their lifetime) [3] and diabetes-associated complications, such as diabetic retinopathy, neuropathy, nephropathy, and cardiovascular disease [4,5]. The 2019 Ninth Edition of the International Diabetes Federation (IDF) atlas reported an estimated cumulative incidence of type 2 diabetes progression 5 years after diagnosis of IGT or IFG between $26 \%$ and $50 \%$, respectively [6]. Moreover, the estimated number of adults aged 20-79 years with IGT was 7.5\% of the world population in this age group (374 million), predicted to rise to $8.0 \%$ (454 million) by 2030 and to $8.6 \%$ (548 million) by 2045 [6]. These estimates are based on IGT only, so the prevalence of prediabetes may be higher if additional criteria are taken into consideration [7].

Insulin resistance and defective glucose sensing at the pancreatic $\beta$-cell are the central pathophysiologic determinants that together cause hyperglycemia. The mechanisms involved include deficient muscle gluconeogenesis, oxidative stress and increased reactive oxygen species (ROS) [8], defective expression or translocation of glucose transporter 4 (GLUT4) [9], imbalance of the phosphatidylinositol 3-kinase (PI3K)/protein kinase B (AKT) (PI3K/AKT) signaling pathway [10], endoplasmic reticulum (ER) stress with activation of unfolded protein response, and activation of the c-Jun N-terminal kinase pathway [11]. On the other hand, prediabetes is considered an underlying etiology of metabolic syndrome [12].

Lifestyle interventions are a very important approach in the management of prediabetes. Changing the modifiable risk factors by targeting obesity with increased physical activity and dietary changes improves insulin sensitivity and preserves $\beta$-cell function [13,14]. Interventions using naturally occurring molecules are a focus of increasing attention as complementary nutritional strategies to ameliorate insulin resistance, glycemic control, and lipid profile. A variety of nutraceutical supplements have been used in clinical practice to ameliorate the underlying mechanisms of insulin resistance, including L-carnitine, $\alpha$ lipoic acid, berberine, omega-3 polyunsaturated fatty acids, and phytochemicals including polyphenols, flavonoids, and phenolic acids [15,16].

Sclerocarya birrea (A. Rich.) Hochst belonging to the Anacardiaceae family (known as marula) is a medium-sized deciduous African tree, where leaves, stem bark, root, and fruits have a wide range of uses in food and traditional medicine. Chemical constituents include ascorbic acid, sesquiterpene hydrocarbons, amino acids, oleic, myristic and stearic fatty acids, tannins, flavonoids, and polyphenols, among others, which have been the basis of biological studies assessing the antioxidant, anti-inflammatory, analgesic, antiparasitic and antimicrobial activity, as well as antidiabetic properties of Sclerocarya birrea [17]. A number of studies in experimental animals have shown the hypoglycemic effect and antidiabetic activity of Sclerocarya birrea [18-21]. These studies showed how Sclerocarya birrea might contribute to different metabolic processes, with a possible mechanism of action similar to $\alpha$-glycosidases and $\alpha$-amylases [18], being involved similarly to sulfonylurea potentiating calcium signaling in beta-cells [19], or enhancing AMPK activation through a mechanism similar to that of biguanides [20]. However, results about human intervention trials were not found in the literature.

Regarding the target pathology, Sclerocarya birrea is used as a traditional remedy for diabetes mellitus from ancient times. In a survey conducted between January and April 2016, a total of 116 diabetic patients distributed in 58 tribes and in all phytogeographic units, previously diagnosed in the hospital of Cameroon, responded to the questionnaire about the use of medicinal plants to treat their disease. Among them, Sclerocarya birrea was used by $48 \%$ of surveyed people. The treatment consisted of boiling $250 \mathrm{~g}$ of stem-bark or $100 \mathrm{~g}$ of leaves in $4 \mathrm{~L}$ of water and drinking $250 \mathrm{~mL}$ of the decoction three times per day [22].

Due to the traditional use of the source Sclerocarya birrea in the ethnopharmacological treatment of diabetes, the objective of the present study was to assess the efficacy of an aqueous extract obtained from the bark of the Sclerocarya birrea tree in the control of glucose metabolism in subjects with prediabetes as compared with placebo. As far as we are aware, this is the first exploratory clinical trial conducted in clinical practice to assess the effect of a 
nutraceutical compound based on Sclerocarya birrea in subjects with a confirmed diagnosis of prediabetes.

\section{Materials and Methods}

\subsection{Study Design and Participants}

This was a single-center, randomized, double-blind, placebo-controlled study with two parallel arms stratified by sex, conducted at the Health Sciences Department of Universidad Católica San Antonio de Murcia (UCAM), in Murcia, Spain. The study began on 1 July 2018 and finished on 13 December 2019. The primary objective of this exploratory study was to assess the effect of a 90-day daily regimen with a dietary nutraceutical supplement based on a natural extract of Sclerocarya birrea on the control of glucose metabolism in subjects diagnosed with prediabetes. Secondary objectives included changes in the lipid profile, endothelial function, inflammatory biomarkers, anthropometric variables, and assessment of the tolerability and safety of the study product. Participants were mainly recruited by advertising the study through mass media and talks in women's centers, elderly community centers, and neighborhood associations. Eligible subjects were Caucasian men and women aged between 18 and 65 years, diagnosed with prediabetes according to ADA criteria [1] ( $\mathrm{HbA} 1 \mathrm{c}$ level of $5.7 \%$ to $6.4 \%$, fasting plasma glucose (FPG) $100-125 \mathrm{mg} / \mathrm{dL}$, oral glucose tolerance test (OGTT) 140-199 mg/dL), body mass index (BMI) between 20 and $35 \mathrm{~kg} / \mathrm{m}^{2}$, and stable nutritional habits with no body weight gain or loss of more than $5 \mathrm{~kg}$ in the last 10 weeks. Exclusion criteria were history of liver or renal dysfunction, alcohol consumption ( $>20 \mathrm{~g} /$ day), use of any drug that may affect glucose metabolism, participation in another clinical trial within the previous 3 months, pregnancy, and ineligibility as judged by the investigators.

The study protocol was approved by the Ethics Committee of Universidad Católica San Antonio (code 6113, approval date 3 June 2016) (Murcia, Spain) and was registered in the ClinicalTrials.gov, accessed on 31 October 2019 (NCT04132908). Written informed consent was obtained from all participants.

\subsection{Intervention and Study Procedures}

Participants were randomly assigned to the intervention group (dietary intervention with the Sclerocarya birrea-based nutritional supplement) or the control group (supplementation with placebo) using the Epidat 3.1 program but ensuring the homogeneity of the study groups regarding sex. Randomization was performed by an independent researcher.

The active product was an encapsulated dry powder aqueous extract obtained from Sclerocarya birrea stem bark. The product (Sclerobigenol ${ }^{\circledR}$ ) was supplied by Herbafor, S.L. (Fortuna, Murcia, Spain) and was manufactured by a combination of physical stages, including air drying of the raw strands of the bark tree after being collected, the grinding of the dry bark to an adequate particle size, an aqueous maceration at ambient temperature for a fixed period of time, the separation of solid matter from the solution by successive filtrations, and the final elimination of water from the eluted solution by steam-distillation and subsequent drying under mild temperature and high vacuum. The resultant product is then sampled for analysis, filled into aseptic bags, labeled, and packed in cardboard boxes until use.

In order to determine the phenolic composition of the final product, a comprehensive characterization of the extract was carried out by high-performance liquid chromatography coupled to electrospray time of flight mass spectrometry (HPLC-ESI-TOF/MS), as described by Jiménez-Sánchez et al. [23]. The quantification of 14 major phenols contained in the extract was also investigated.

The major compound identified (Figure 1) was gallic acid (compound a; $1588 \mu \mathrm{g} / \mathrm{g}$ on average), constituting $45 \%$ of the total phenolic fraction quantified. Other major representative compounds were epigallocatechin gallate (compound $\mathrm{b}$ and isomers $\mathrm{b} 1$ and $\mathrm{b} 2,593 \mu \mathrm{g} / \mathrm{g}$ on average), representing $17 \%$ of the total, and procyanidin B2 di-O-gallate (compound c and isomer $\mathrm{c} 1,511 \mu \mathrm{g} / \mathrm{g}$ on average), with $15 \%$ of the total. 


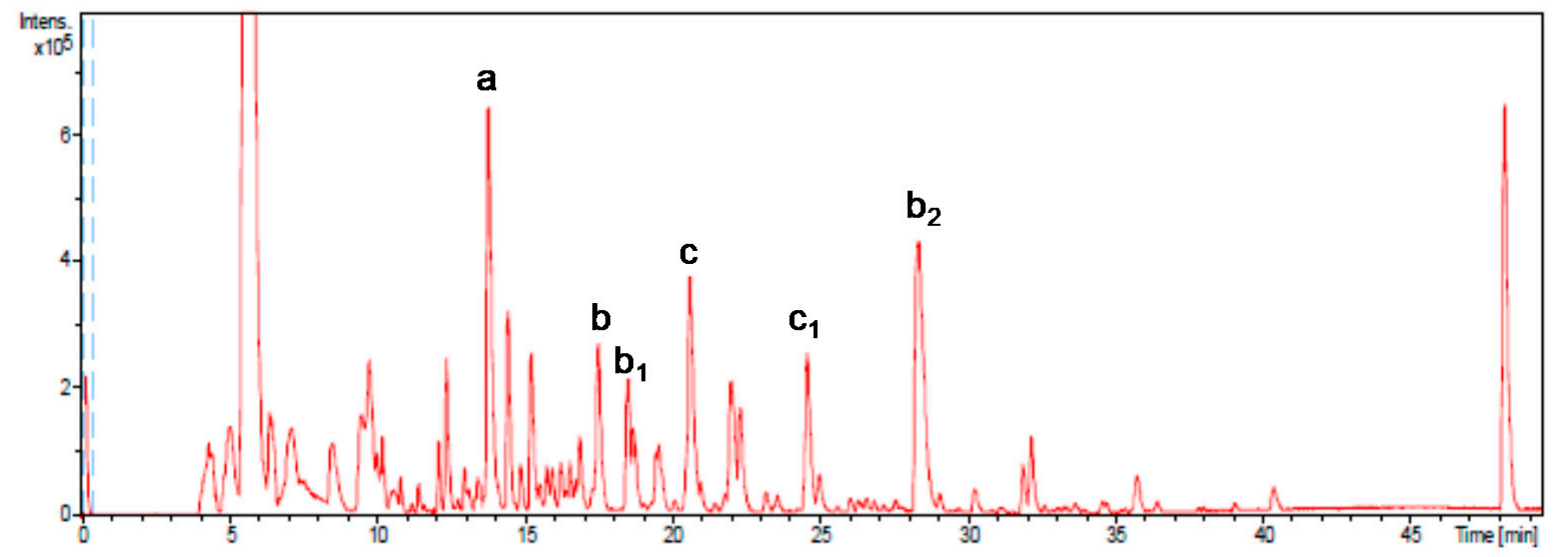

Figure 1. Base peak chromatogram obtained by HPLC-SI-TOF/ MS. More representative peaks such as gallic acid (a), epigallocatechin gallate $(b)$, isomers $\left(b_{1}\right.$ and $\left.b_{2}\right)$, procyanidin B2-3,3-di-O-gallate $(c)$, and isomer $\left(c_{1}\right)$ have been identified.

The stability of the powder extract in capsule formulation was investigated for a period of 90 days, under accelerated conditions (stored at $40{ }^{\circ} \mathrm{C}$ and $45 \%$ humidity), by total phenolic compounds determination and quantitative analysis of more representative compounds of the phenolic profile, according to Jiménez-Sánchez et al. (2015) [23].

The analysis of the total phenolic compounds in the capsules by the Folin-Ciocalteu method remained unchanging after 90 days of storage in accelerated conditions. In general, catechin provided losses during storage, but the increase of gallic and epicatechin levels balanced the catechin loss, maintaining the global phenolics variations of the compounds. Therefore, it can be considered that the capsules show normal stability behavior during storage under accelerated conditions when using phenolic compounds as reference stability markers.

The qualitative composition of the product includes a variety of 95 components, including organic acids, polyphenols, fatty acids derivatives, etc., being that polyphenols, especially dimers of epicatechins, epigallocatechins, epigallocatechin gallate, procyanidin B2-3,3-di-O-gallate, and organic acids such as gallic acid are the most relevant. All participants followed the same regimen of taking two capsules/day of the study product at the time of breakfast and dinner for 90 days. Subjects who were assigned to the experimental group received the active product ( 2 capsules/day, $2 \times 50 \mathrm{mg}$ each), and those assigned to the control group received identical-appearing placebo capsules (maltodextrin).

Participants were visited at baseline (visit 1 ) and at 40 (visit 2) and 90 days (final visit). At the baseline visit, the written informed consent was obtained, and fulfillment of the inclusion criteria was checked. The study product was provided at visits 1 and 2. Clinical assessments at each study visit included detailed medical history, measurement of glucose metabolism variables, lipid profile, anthropometric variables, blood pressure, brachial artery plethysmography (performed at baseline and at the final visit), and biomarkers of inflammation. Venous blood samples were taken after $12 \mathrm{~h}$ fasting at each of the visits for laboratory analysis. Participants were advised against performing moderate or severe physical exercise for at least 1 day before blood sampling. Alterations in dietary habits and the use of other nutritional supplements were not allowed during the study. The returned capsules at visits 2 and 3 (end of the study) were checked and counted for adherence with the study product. Participants were directly asked for adverse events, and results of laboratory analyses were assessed for normality.

\subsection{Study Variables}

Glucose metabolism variables included the area under the curve (AUC) of OGTT ( $2 \mathrm{~h}$ OGTT after $12 \mathrm{~h}$ overnight fasting, $75 \mathrm{~g}$ glucose, capillary blood samples obtained at 0 , $15,30,45,60,90$, and $120 \mathrm{~min}$ ), which was calculated based on the AUC at fasting serum glucose and based on the X-axis at glucose concentration of $0 \mathrm{mg} / \mathrm{dL}$ (AUC at $0 \mathrm{mg} / \mathrm{dL}$ ), 
using the trapezoidal method for both variables: $1 \mathrm{~h}$ and $2 \mathrm{~h}$ post-OGTT glucose levels, serum $\mathrm{HbA1c}$ by high-performance liquid chromatography, fasting serum glucose (clinical chemistry analyzer B400 ByoSystems) and insulin levels, insulin/glucose ratio, homeostatic model assessment: insulin resistance (HOMA-IR) with a cut-off of $>3.2$ for diagnosis of IR; HOMA- $\beta 1$, the Quantitative Insulin Sensitivity Check Index (QUICKI) with a cut-off of $<0.35$ for diagnosis of IR, lipid profile (cholesterol, low-density lipoprotein cholesterol (LDLC), high-density lipoprotein cholesterol (HDL-C) and triglycerides) (B400 ByoSystems), blood pressure (BP), flow-mediated dilation (FMD) as a measure of endothelial function, anthropometric variables (body weight, BMI, hip circumference, waist-to-hip ratio, and free fat mass), and inflammation-related biomarkers (E-selectin, interleukin-6 (IL-6)).

Blood pressure was measured coinciding with blood withdrawal in the morning using an OMRON M6 AC blood pressure monitor (Omron Healthcare España).

The measurement of blood pressure was performed with an OMRON M6 AC blood pressure monitor (Omron Healthcare España) at the time of peripheral blood sampling. Blood pressure was recorded after participants were comfortably seated in a quiet room for $5 \mathrm{~min}$. Blood pressure values were the average of three measurements taken $2 \mathrm{~min}$ apart [24]. FMD was measured following the recommendations of the International Brachial Reactivity Task Force [25] in the brachial artery. We used high-resolution echo-Doppler ultrasound equipment (SonoSite MicroMaxx HFL38) with a 6-13 MHz linear array transducer. After placing a blood pressure sphygmomanometer cuff above the antecubital fossa, the brachial artery diameter was measured following the acquisition of a baseline resting image. The cuff was then inflated up to suprasystolic pressure for $5 \mathrm{~min}$ in order to provoke arterial occlusion, and a new measurement was obtained after $1 \mathrm{~min}$ of deflating the cuff. FMD was determined using the equation: (peak of hyperemia diameter) - (baseline diameter) $/$ (baseline diameter) $\times 100$, with results after occlusion expressed as the percentage of arterial diameter change $(\mathrm{mm})$ in response to hyperemia as compared to the baseline diameter. All measurements were taken by the same investigator. Bio-impedance analysis (BIA) was used to determine free fat mass using a whole-body BIA analyzer Tanita BC-420MA (Tanita Corporation, Arlington Heights, IL, USA). Serum levels of E-selectin and IL-6 were measured by E-selectin and IL-6 High Sensitivity ELISA kits (IBL International, GmbH, Hamburg, Germany).

Safety variables were assessed in the following laboratory tests: complete hemogram; liver functions tests, including bilirubin, aspartate aminotransferase (AST), alanine aminotransferase (ALT), gamma-glutamyl transpeptidase (GGT) and lactate dehydrogenase (LDH); as well as serum creatinine levels and blood urea nitrogen.

Physical activity was measured using the Global Physical Activity Questionnaire (GPAQ) [26], and participants were classified into four categories: inactive (1), moderately inactive (2), moderately active (3), and very active (4).

\subsection{Statistical Analysis}

The sample size was calculated according to the AUC during OTTG as the main variable of the study. Considering a standard deviation of AUC during OTTG of $786 \mathrm{mg} \cdot \mathrm{min} / \mathrm{dL}$ reported in a similar population [27], for a precision of $500 \mathrm{mg} \cdot \mathrm{min} / \mathrm{dL}$ with an alpha risk of $5 \%$ and statistical power of $80 \%, 32$ subjects in each group were needed, increasing to 35 subjects per group assuming a 10\% loss to follow-up.

The analysis was performed by a non-blinded statistician according to the doubleblind design of the study and was based on the per-protocol (PP) data set corresponding to those participants who finished the study at 90 days. The AUC of OGTT was the primary outcome of the study and the other variables were secondary outcomes. Categorical variables are expressed as frequencies and percentages and continuous variables as mean \pm standard deviation (SD). The chi-square $\left(\chi^{2}\right)$ test or the Fisher's exact test were used for the comparison of categorical variables between the study groups, and the analysis of variance (ANOVA) for repeated measures with two study factors: the within-subject factor (time: baseline, 40 days, and 90 days) and between-subject factor (intervention: active 
product and placebo) for paired data. The $\mathrm{G}^{*}$ Power 3.1 program was used to calculate statistical power. The SPSS version 21.0 (IBM Corp., Armonk, NY, USA) was used for data analysis, with a $p<0.05$ value as statistically significant.

\section{Results}

Of a total of 105 voluntary subjects, 35 were excluded because the inclusion criteria were not met. The remaining 70 subjects were randomized ( 35 to each study group), but two subjects assigned to the experimental group and one assigned to the placebo group were lost to follow-up. Therefore, the final study population included 67 subjects ( 33 in the experimental group, 34 in the placebo group), 36 men and 31 women, with a mean age of $32.3 \pm 14.1$ years (Figure 2). Baseline characteristics of participants are shown in Table 1.

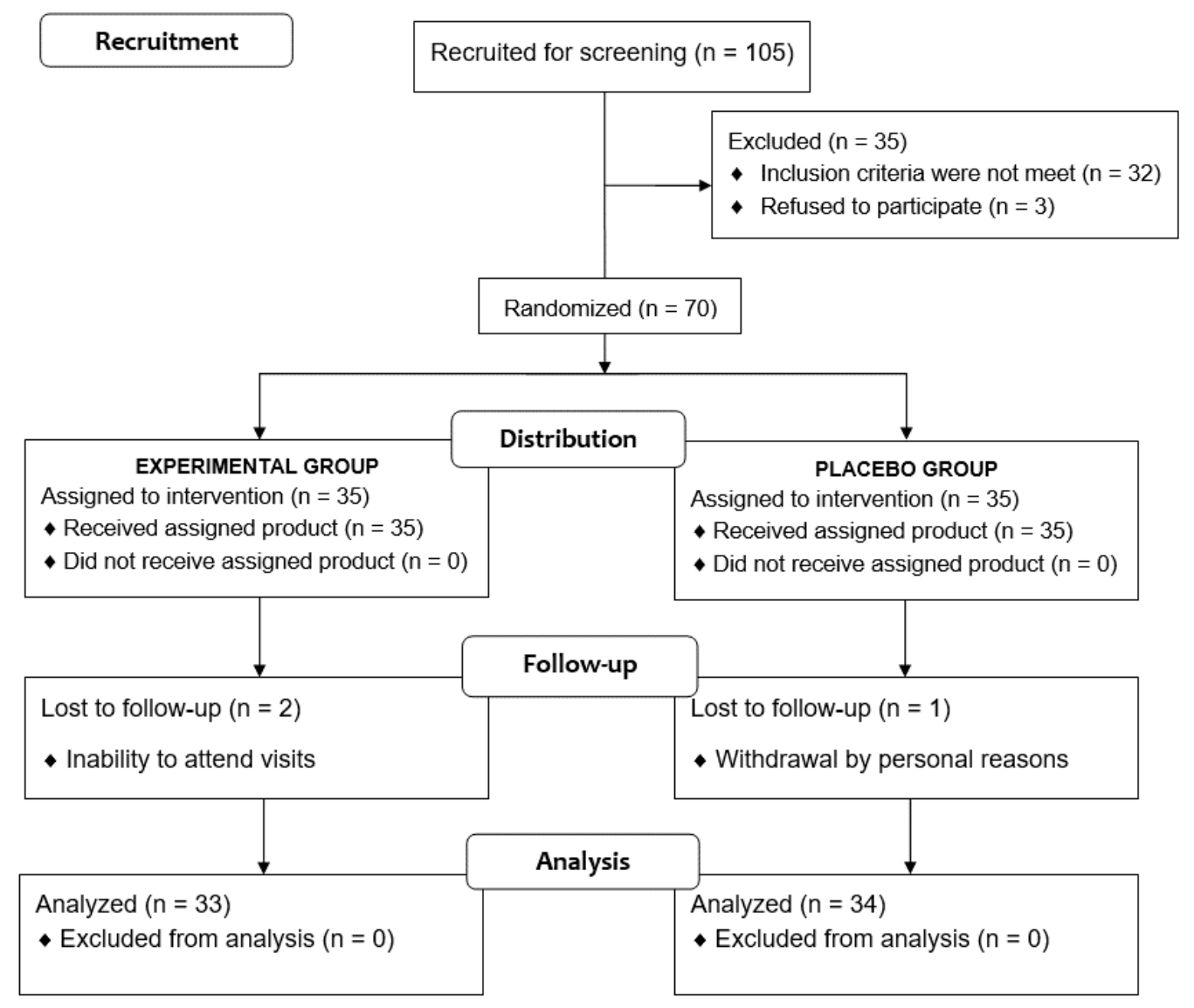

Figure 2. Flow chart of the study population.

Table 1. Baseline characteristics of participants.

\begin{tabular}{ccc}
\hline Variables & $\begin{array}{c}\text { Control } \\
\text { Group }(\mathbf{n}=\mathbf{3 3})\end{array}$ & $\begin{array}{c}\text { Experimental } \\
\text { Group }(\mathbf{n}=\mathbf{3 4})\end{array}$ \\
\hline Gender & & \\
Men & 17 & 19 \\
Women & 16 & 15 \\
Age, years, mean $\pm \mathrm{SD}$ & $31.5 \pm 15.2$ & $33.1 \pm 13.2$ \\
Physical activity, $\%$ & & 33.3 \\
1 (inactive) & 29.4 & 15.2 \\
2 (moderately inactive) & 17.6 & 24.2 \\
3 (moderately active) & 29.4 & 27.3 \\
4 (very active) & 23.5 &
\end{tabular}




\subsection{Glucose Metabolism}

Changes in the different variables of glucose metabolism in the control and experimental groups during the study period are shown in Table 2.

Table 2. Results of changes in glucose metabolism after a 90-day use of a nutraceutical supplement of Sclerocarya birrea or placebo in subjects with prediabetes.

\begin{tabular}{|c|c|c|c|c|c|}
\hline \multirow[b]{2}{*}{ Variables } & \multirow{2}{*}{$\begin{array}{c}\text { Pre-Intervention } \\
\text { Baseline }\end{array}$} & \multicolumn{2}{|c|}{ Intervention Period } & \multicolumn{2}{|c|}{ Significant Differences } \\
\hline & & 40 Days & 90 Days & $\begin{array}{l}\text { Within-Group } \\
p \text { Value }\end{array}$ & $\begin{array}{c}\text { Between-Group } \\
p \text { Value }\end{array}$ \\
\hline \multicolumn{6}{|l|}{$\begin{array}{l}\text { AUC of OGTT, } \mathrm{mg} \cdot \mathrm{min} / \mathrm{dL} \\
\text { (at fasting serum glucose) }\end{array}$} \\
\hline Control group $(n=34)$ & $4755 \pm 2265$ & $4394 \pm 1879$ & $4636 \pm 1969$ & 1.0 & \multirow[b]{2}{*}{$<0.004$} \\
\hline $\begin{array}{l}\text { Experimental group } \\
(\mathrm{n}=33)\end{array}$ & $5286 \pm 2260$ & $4526 \pm 2543$ & $3786 \pm 1817$ & $<0.001$ & \\
\hline \multicolumn{6}{|l|}{$\begin{array}{l}\text { AUC of OGTT, } \mathrm{mg} \cdot \mathrm{min} / \mathrm{dL} \\
(\text { at } 0 \mathrm{mg} / \mathrm{dL})\end{array}$} \\
\hline Control group $(n=34)$ & $17,401 \pm 2284$ & $16,892 \pm 1933$ & $17,229 \pm 2152$ & 1.0 & \multirow[b]{2}{*}{$<0.002$} \\
\hline $\begin{array}{l}\text { Experimental group } \\
\qquad(\mathrm{n}=33)\end{array}$ & $17,809 \pm 2534$ & $16,908 \pm 2825$ & $16,219 \pm 2176$ & $<0.001$ & \\
\hline \multicolumn{6}{|c|}{ Glucose peak at OGTT, mg/dL } \\
\hline Control group $(\mathrm{n}=34)$ & $179 \pm 29$ & $174 \pm 25$ & $175 \pm 22$ & 1.0 & \multirow[b]{2}{*}{$<0.011$} \\
\hline $\begin{array}{l}\text { Experimental group } \\
(\mathrm{n}=33)\end{array}$ & $181 \pm 34$ & $170 \pm 32$ & $161 \pm 28$ & $<0.001$ & \\
\hline \multicolumn{6}{|l|}{$\mathrm{HbA} 1 \mathrm{c}, \%$} \\
\hline $\begin{array}{l}\text { Control group } \\
(\mathrm{n}=34)\end{array}$ & $5.22 \pm 0.36$ & $5.23 \pm 0.40$ & $5.22 \pm 0.37$ & 1.0 & \multirow{2}{*}{0.469} \\
\hline $\begin{array}{l}\text { Experimental group } \\
\qquad(\mathrm{n}=33)\end{array}$ & $5.33 \pm 0.44$ & $5.35 \pm 0.42$ & $5.24 \pm 0.43$ & 0.543 & \\
\hline \multicolumn{6}{|c|}{ Fasting serum glucose, $\mathrm{mg} / \mathrm{dL}$} \\
\hline $\begin{array}{l}\text { Control group } \\
\quad(\mathrm{n}=34)\end{array}$ & $103.4 \pm 3.0$ & $102.6 \pm 4.9$ & $103.6 \pm 5.4$ & 1.0 & \multirow{2}{*}{0.107} \\
\hline $\begin{array}{l}\text { Experimental group } \\
\qquad(\mathrm{n}=33)\end{array}$ & $104.2 \pm 5.0$ & $104.3 \pm 5.9$ & $102.9 \pm 5.3$ & 0.329 & \\
\hline \multicolumn{6}{|c|}{ Fasting serum insulin, $\mathrm{mU} / \mathrm{L}$} \\
\hline $\begin{array}{l}\text { Control group } \\
\quad(\mathrm{n}=34)\end{array}$ & $9.36 \pm 6.55$ & $10.80 \pm 8.09$ & $10.16 \pm 6.18$ & 1.0 & \multirow{2}{*}{$<0.027$} \\
\hline $\begin{array}{l}\text { Experimental group } \\
\qquad(\mathrm{n}=33)\end{array}$ & $9.78 \pm 6.82$ & $7.70 \pm 5.07$ & $8.11 \pm 4.46$ & 0.148 & \\
\hline \multicolumn{6}{|l|}{ HOMA-IR } \\
\hline $\begin{array}{l}\text { Control group } \\
\quad(\mathrm{n}=34)\end{array}$ & $2.40 \pm 1.70$ & $2.76 \pm 2.13$ & $2.61 \pm 1.62$ & 1.0 & \multirow{2}{*}{$<0.034$} \\
\hline $\begin{array}{l}\text { Experimental group } \\
\qquad(\mathrm{n}=33)\end{array}$ & $2.54 \pm 1.80$ & $2.01 \pm 1.38$ & $2.08 \pm 1.20$ & 0.313 & \\
\hline \multicolumn{6}{|l|}{ QUICKI index } \\
\hline $\begin{array}{l}\text { Control group } \\
\quad(\mathrm{n}=34)\end{array}$ & $0.35 \pm 0.03$ & $0.34 \pm 0.03$ & $0.34 \pm 0.03$ & 0.632 & \multirow{2}{*}{$<0.034$} \\
\hline $\begin{array}{l}\text { Experimental group } \\
(\mathrm{n}=33)\end{array}$ & $0.35 \pm 0.03$ & $0.36 \pm 0.03$ & $0.35 \pm 0.03$ & 0.07 & \\
\hline
\end{tabular}


Table 2. Cont.

\begin{tabular}{|c|c|c|c|c|c|}
\hline \multirow[b]{2}{*}{ Variables } & \multirow{2}{*}{$\begin{array}{c}\text { Pre-Intervention } \\
\text { Baseline }\end{array}$} & \multicolumn{2}{|c|}{ Intervention Period } & \multicolumn{2}{|c|}{ Significant Differences } \\
\hline & & 40 Days & 90 Days & $\begin{array}{l}\text { Within-Group } \\
\quad p \text { Value }\end{array}$ & $\begin{array}{c}\text { Between-Group } \\
p \text { Value }\end{array}$ \\
\hline \multicolumn{6}{|l|}{ HOMA- $\beta 1$} \\
\hline $\begin{array}{l}\text { Control group } \\
\quad(\mathrm{n}=34)\end{array}$ & $83.29 \pm 55.81$ & $98.49 \pm 73.12$ & $89.82 \pm 50.68$ & 1.0 & \multirow{2}{*}{$<0.027$} \\
\hline $\begin{array}{l}\text { Experimental group } \\
\qquad(\mathrm{n}=33)\end{array}$ & $89.41 \pm 65.51$ & $70.94 \pm 42.30$ & $75.47 \pm 39.21$ & 0.438 & \\
\hline \multicolumn{6}{|l|}{ Insulin/glucose ratio } \\
\hline $\begin{array}{l}\text { Control group } \\
\quad(\mathrm{n}=34)\end{array}$ & $0.09 \pm 0.06$ & $0.10 \pm 0.08$ & $0.10 \pm 0.06$ & 1.0 & \multirow{2}{*}{$<0.022$} \\
\hline $\begin{array}{l}\text { Experimental group } \\
\qquad(\mathrm{n}=33)\end{array}$ & $0.09 \pm 0.07$ & $0.07 \pm 0.05$ & $0.08 \pm 0.04$ & 0.280 & \\
\hline \multicolumn{6}{|l|}{$\begin{array}{l}1 \mathrm{~h} \text { post-OGTT } \\
\text { glucose, } \mathrm{mg} / \mathrm{dL}\end{array}$} \\
\hline $\begin{array}{l}\text { Control group } \\
\quad(\mathrm{n}=34)\end{array}$ & $161.09 \pm 36.07$ & $155.71 \pm 27.56$ & $155.00 \pm 29.50$ & 0.798 & \multirow{2}{*}{0.081} \\
\hline $\begin{array}{l}\text { Experimental group } \\
\qquad(\mathrm{n}=33)\end{array}$ & $168.52 \pm 39.10$ & $154.03 \pm 39.42$ & $156.91 \pm 31.11$ & $<0.001$ & \\
\hline \multicolumn{6}{|l|}{$\begin{array}{l}2 \mathrm{~h} \text { post-OGTT } \\
\text { glucose, } \mathrm{mg} / \mathrm{dL}\end{array}$} \\
\hline $\begin{array}{l}\text { Control group } \\
(\mathrm{n}=34)\end{array}$ & $121.35 \pm 23.86$ & $119.53 \pm 20.90$ & $124.00 \pm 23.38$ & 1.0 & \multirow{2}{*}{$<0.050$} \\
\hline $\begin{array}{l}\text { Experimental group } \\
\qquad(\mathrm{n}=33)\end{array}$ & $125.79 \pm 23.27$ & $121.09 \pm 22.01$ & $117.12 \pm 20.55$ & $<0.028$ & \\
\hline
\end{tabular}

In relation to the AUC of OGTT as the primary outcome of the study (both at fasting glucose level and at min 0), statistically significant decreases in the experimental group at 40 and 90 days as compared with baseline were found, whereas significant changes in the placebo group were not observed. Between-group differences were statistically significant (Figure 3). Similar findings were observed in glucose peak levels at OGTT, with significant decreases in the experimental group at 40 and 90 days $(p<0.001)$, and between-group differences $(p<0.011)$. Changes in $\mathrm{HbA1c}$ and fasting serum glucose levels were not observed in any of the groups throughout the study period. However, there were differences in insulin-related markers, with statistically significant differences between the experimental and control groups for fasting serum insulin levels $(p<0.027)$, HOMA-IR $(p<0.034)$, and QUICKI index $(p<0.034)$.

\subsection{Flow-Mediated Dilation}

The use of the nutraceutical product of Sclerocarya birrea over a period of 90 days was associated with an improvement in flow-mediated dilation (FMD). The comparison of baseline $(6.51 \pm 5.11 \%)$ and final values $(8.61 \pm 5.22 \%)$ showed statistically significant differences in the experimental group $(p<0.040$, statistical power $37 \%)$. Changes in the control group were not significant $(7.76 \pm 5.04 \%$ vs. $7.14 \pm 5.91 \%, p=0.505$, statistical power $7.4 \%)$. Between-group differences were statistically significant $(p<0.05)$ (Figure 4$)$. 


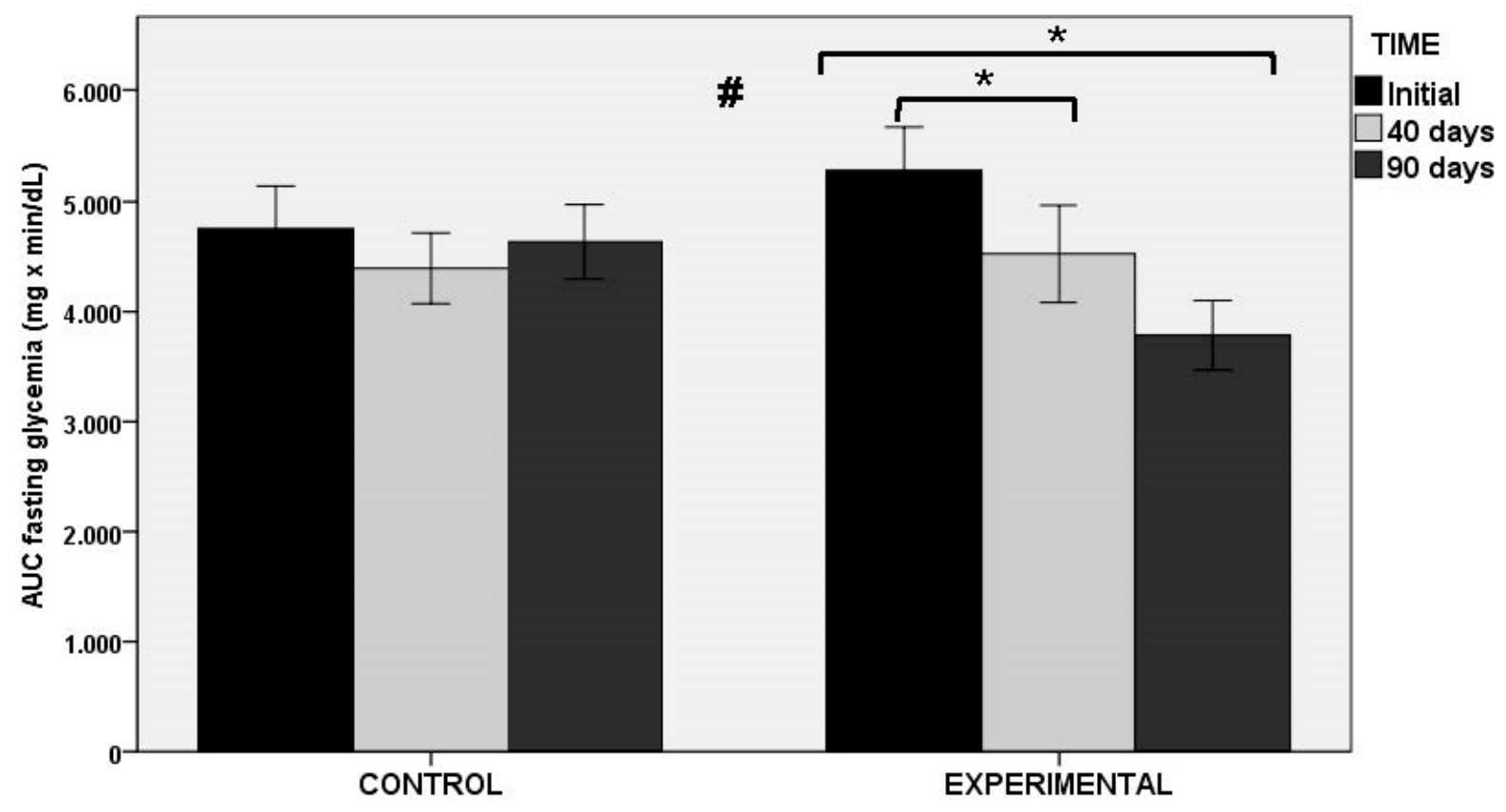

Figure 3. AUC of OGTT at fasting glycemia in the control and experimental groups; ${ }^{*} p<0.001$ for within-group comparisons in the experimental group; $\# p<0.004$ for the comparison between control and experimental groups.

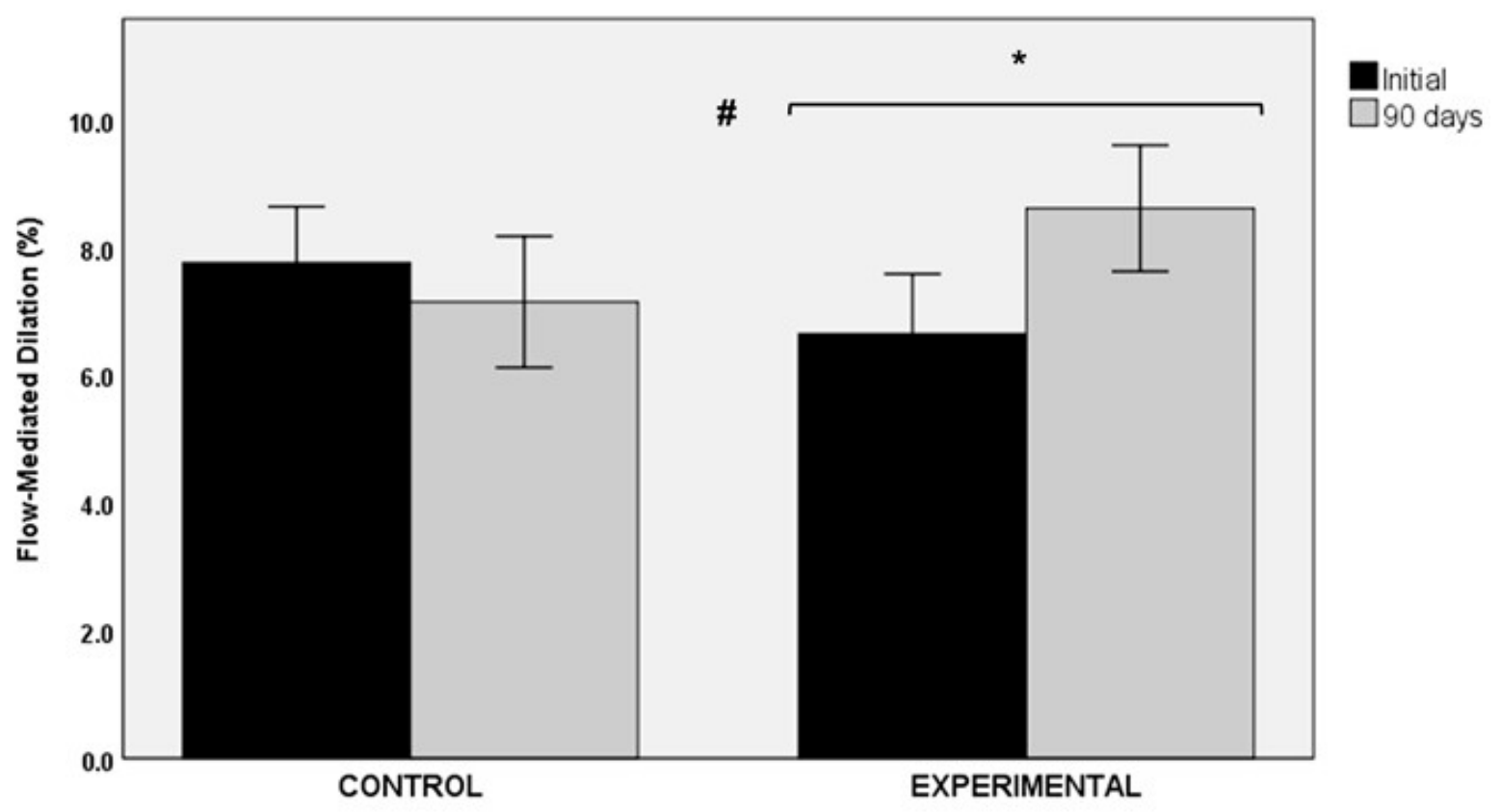

Figure 4. Changes in flow-mediated dilation (FMD) in the control and experimental groups; $p<0.040$ for within-group comparison in the experimental group; $\# p<0.05$ for the comparison between the control and the experimental groups.

\subsection{Lipid Profile}

As shown in Table 3, statistically significant changes in the serum cholesterol, LDLC, HDL-C, and triglycerides during the study period were not observed either in the experimental or in the control group. 
Table 3. Changes in the lipid profile after a 90-day use of a nutraceutical supplement of Sclerocarya birrea or placebo in subjects with prediabetes.

\begin{tabular}{|c|c|c|c|c|c|}
\hline \multirow[b]{2}{*}{ Variables } & \multirow{2}{*}{$\begin{array}{c}\text { Pre-Intervention } \\
\text { Baseline }\end{array}$} & \multicolumn{2}{|c|}{ Intervention Period } & \multicolumn{2}{|c|}{ Significant Differences } \\
\hline & & 40 Days & 90 Days & $\begin{array}{l}\text { Within-Group } \\
p \text { Value }\end{array}$ & $\begin{array}{c}\text { Between-Group } \\
p \text { Value }\end{array}$ \\
\hline \multicolumn{6}{|l|}{ Serum cholesterol, mg/dL } \\
\hline Control group $(\mathrm{n}=34)$ & $194 \pm 34$ & $192 \pm 36$ & $198 \pm 41$ & 1.0 & \multirow[b]{2}{*}{0.641} \\
\hline $\begin{array}{l}\text { Experimental group } \\
(\mathrm{n}=33)\end{array}$ & $191 \pm 36$ & $187 \pm 38$ & $189 \pm 38$ & 1.0 & \\
\hline \multicolumn{6}{|l|}{ LDL-C, mg/dL } \\
\hline Control group $(n=34)$ & $113.4 \pm 25.2$ & $114.8 \pm 33.7$ & $118.1 \pm 28.1$ & 0.610 & \multirow[b]{2}{*}{0.662} \\
\hline $\begin{array}{l}\text { Experimental group } \\
\qquad(\mathrm{n}=33)\end{array}$ & $102.8 \pm 27.2$ & $108.1 \pm 30.7$ & $111.4 \pm 34.6$ & 0.851 & \\
\hline \multicolumn{6}{|l|}{ HDL-C, mg/dL } \\
\hline Control group $(n=34)$ & $60.1 \pm 15.1$ & $59.0 \pm 15.3$ & $58.1 \pm 13.2$ & 0.252 & \multirow[b]{2}{*}{0.639} \\
\hline $\begin{array}{l}\text { Experimental group } \\
(\mathrm{n}=33)\end{array}$ & $59.9 \pm 12.1$ & $58.3 \pm 12.1$ & $59.1 \pm 10.8$ & 1.0 & \\
\hline \multicolumn{6}{|l|}{ Serum triglycerides, $\mathrm{mg} / \mathrm{dL}$} \\
\hline Control group $(\mathrm{n}=34)$ & $94 \pm 57$ & $99 \pm 61$ & $99 \pm 54$ & 1.0 & \multirow[b]{2}{*}{0.101} \\
\hline $\begin{array}{l}\text { Experimental group } \\
(\mathrm{n}=33)\end{array}$ & $98 \pm 54$ & $87 \pm 48$ & $89 \pm 42$ & 0.531 & \\
\hline
\end{tabular}

\subsection{Anthropometric Variables}

Anthropometric variables did not show statistically significant changes in subjects assigned to the control or the experimental group over the 90-day study period (Table 4).

Table 4. Changes in anthropometric variables after a 90-day use of a nutraceutical supplement of Sclerocarya birrea or placebo in subjects with prediabetes.

\begin{tabular}{|c|c|c|c|c|c|}
\hline \multirow[b]{2}{*}{ Variables } & \multirow{2}{*}{$\begin{array}{c}\text { Pre-Intervention } \\
\text { Baseline }\end{array}$} & \multicolumn{2}{|c|}{ Intervention Period } & \multicolumn{2}{|c|}{ Significant Differences } \\
\hline & & 40 Days & 90 Days & $\begin{array}{l}\text { Within-Group } \\
\quad p \text { Value }\end{array}$ & $\begin{array}{c}\text { Between-Group } \\
p \text { Value }\end{array}$ \\
\hline \multicolumn{6}{|l|}{ Body weight, kg } \\
\hline Control group $(n=34)$ & $75.2 \pm 18.2$ & $75.2 \pm 18.1$ & $75.2 \pm 17.9$ & 1.0 & \multirow[b]{2}{*}{0.469} \\
\hline $\begin{array}{l}\text { Experimental group } \\
\qquad(\mathrm{n}=33)\end{array}$ & $75.2 \pm 18.3$ & $74.9 \pm 18.3$ & $74.7 \pm 18.3$ & 0.543 & \\
\hline \multicolumn{6}{|l|}{ Body mass index $(\mathrm{BMI}), \mathrm{kg} / \mathrm{m}^{2}$} \\
\hline Control group $(n=34)$ & $26.1 \pm 5.3$ & $26.1 \pm 5.2$ & $26.1 \pm 5.2$ & 1.0 & \multirow[b]{2}{*}{0.261} \\
\hline $\begin{array}{l}\text { Experimental group } \\
\qquad(\mathrm{n}=33)\end{array}$ & $25.9 \pm 6.9$ & $25.9 \pm 6.9$ & $25.8 \pm 7.0$ & 0.304 & \\
\hline \multicolumn{6}{|l|}{ Fat mass, $\%$} \\
\hline Control group $(\mathrm{n}=34)$ & $25.4 \pm 9.3$ & $25.3 \pm 9.3$ & $25.4 \pm 9.0$ & 1.0 & \multirow[b]{2}{*}{0.890} \\
\hline $\begin{array}{l}\text { Experimental group } \\
\qquad(\mathrm{n}=33)\end{array}$ & $29.1 \pm 10.4$ & $29.1 \pm 10.6$ & $29.3 \pm 10.4$ & 1.0 & \\
\hline \multicolumn{6}{|l|}{ Waist-to-hip ratio } \\
\hline Control group $(\mathrm{n}=34)$ & $0.79 \pm 0.09$ & $0.79 \pm 0.10$ & $0.79 \pm 0.10$ & 1.0 & \multirow[b]{2}{*}{0.928} \\
\hline $\begin{array}{l}\text { Experimental group } \\
\qquad(\mathrm{n}=33)\end{array}$ & $0.79 \pm 0.10$ & $0.78 \pm 0.10$ & $0.79 \pm 0.10$ & 1.0 & \\
\hline
\end{tabular}




\subsection{Inflammatory Biomarkers}

Changes in inflammatory biomarkers are shown in Table 5. Mean serum levels of IL-6 were $4.37 \pm 1.37$ and $4.34 \pm 1.79 \mathrm{pg} / \mathrm{mL}$ at baseline in the control and experimental groups, respectively, and at the end of the study, the corresponding values were $4.36 \pm 1.41$ and $4.08 \pm 1.41 \mathrm{pg} / \mathrm{mL}$. Within-group differences were not significant (control group, $p=1.0$; experimental group, $p=0.159$ ). Additionally, statistically significant differences in the between-group comparison were not found $(p=0.284)$.

Table 5. Changes in inflammatory biomarkers and blood pressure after 90-day use of a nutraceutical supplement of Sclerocarya birrea or placebo in subjects with prediabetes.

\begin{tabular}{|c|c|c|c|c|c|}
\hline \multirow[b]{2}{*}{ Variables } & \multirow{2}{*}{$\begin{array}{c}\text { Pre-Intervention } \\
\text { Baseline }\end{array}$} & \multicolumn{2}{|c|}{ Intervention Period } & \multicolumn{2}{|c|}{ Significant Differences } \\
\hline & & 40 Days & 90 Days & $\begin{array}{l}\text { Within-Group } \\
\quad p \text { Value }\end{array}$ & $\begin{array}{c}\text { Between-Group } \\
p \text { Value }\end{array}$ \\
\hline \multicolumn{6}{|l|}{ IL-6, pg/mL } \\
\hline Control group $(n=34)$ & $4.37 \pm 1.37$ & $4.43 \pm 1.25$ & $4.36 \pm 1.41$ & 1.0 & \multirow[b]{2}{*}{0.284} \\
\hline $\begin{array}{l}\text { Experimental group } \\
\qquad(\mathrm{n}=33)\end{array}$ & $4.34 \pm 1.79$ & $4.17 \pm 1.71$ & $4.08 \pm 1.41$ & 0.159 & \\
\hline \multicolumn{6}{|l|}{ E-selectin, ng/mL } \\
\hline Control group $(n=34)$ & $16.62 \pm 1.53$ & $16.59 \pm 1.45$ & $16.23 \pm 0.96$ & 0.878 & \multirow[b]{2}{*}{0.001} \\
\hline $\begin{array}{l}\text { Experimental group } \\
(\mathrm{n}=33)\end{array}$ & $17.59 \pm 1.11$ & $16.52 \pm 0.99$ & $15.70 \pm 1.06$ & 0.001 & \\
\hline \multicolumn{6}{|l|}{ Blood pressure (BP) } \\
\hline \multicolumn{6}{|l|}{ Systolic BP, mmHg } \\
\hline Control group $(n=34)$ & $120 \pm 18$ & $119 \pm 17$ & $120 \pm 16$ & 1.0 & \multirow[b]{2}{*}{0.259} \\
\hline $\begin{array}{l}\text { Experimental group } \\
\qquad(\mathrm{n}=33)\end{array}$ & $125 \pm 18$ & $122 \pm 18$ & $119 \pm 17$ & 0.001 & \\
\hline \multicolumn{6}{|l|}{ Diastolic BP, mmHg } \\
\hline Control group $(\mathrm{n}=34)$ & $76 \pm 11$ & $78 \pm 10$ & $76 \pm 9$ & 1.0 & \multirow[b]{2}{*}{0.132} \\
\hline $\begin{array}{l}\text { Experimental group } \\
\qquad(\mathrm{n}=33)\end{array}$ & $78 \pm 10$ & $76 \pm 11$ & $76 \pm 12$ & 0.265 & \\
\hline
\end{tabular}

However, serum levels of E-selectin were similar at baseline (16.62 \pm 1.53 vs., $17.59 \pm 1.11 \mathrm{ng} / \mathrm{mL}$ in the control and experimental groups, respectively), but showed a significant decrease in the experimental group at the end of the study $(15.70 \pm 1.06$ $\mathrm{ng} / \mathrm{mL})(p<0.001)$, whereas changes in controls were not significant $(16.23 \pm 0.96 \mathrm{ng} / \mathrm{mL})$ $(p=0.295)$. Between-group differences in this variable were statistically significant $(p<0.001)$.

\subsection{Blood Pressure}

Changes in blood pressure are shown in Table 5. In the control group, the mean systolic $\mathrm{BP}$ (SBP) was $120 \pm 18 \mathrm{mmHg}$ at baseline and $120 \pm 16 \mathrm{mmHg}$ at the end of the study $(p=1.0)$. In the experimental group, the mean SBP was $125 \pm 18 \mathrm{mmHg}$ at baseline and $119 \pm 17 \mathrm{mmHg}$ at the end of the study $(p<0.001)$. However, significant between-group differences were not observed $(p=0.259)$. In relation to diastolic BP (DBP), differences both in the control group (baseline $76 \pm 11 \mathrm{mmHg}$ vs. end of study $76 \pm 9 \mathrm{mmHg} ; p=1.0$ ) and in the experimental group (baseline $78 \pm 10 \mathrm{mmHg}$ vs. end of study $76 \pm 12 \mathrm{mmHg}$; $p=0.265)$ were not significant. Additionally, between-group differences were not significant $(p=0.132)$.

In relation to physical activity, statistically significant differences between baseline and the end of the study were not observed either in the control group $(p=0.475)$ or in the experimental group $(p=0.127)$. 
The study products were well tolerated and no adverse effects were recorded. All participants consumed a percentage higher than $90 \%$ of capsules.

\section{Discussion}

The administration for 90 days of a nutraceutical product based on a natural extract of Sclerocarya birrea in subjects diagnosed with prediabetes was associated with an improvement of the AUC during OGTT, measured using either the basal glycemia or at $0 \mathrm{mg} / \mathrm{dL}$. Improvements were statistically significant in subjects assigned to the experimental group, whereas differences among those taking placebo (controls) were not found. As may be expected, improvements in glucose peak during OGTT were also significant in the experimental group only. These effects on glycemic control in the experimental group were also associated with decreases in insulin levels and markers of insulin resistance. Improvement of insulin resistance in the experimental group is supported by post-intervention decreases of insulin/glucose ratio and HOMAR-IR. Although decreases in HOMA- $\beta 1$ in the experimental group could be interpreted as a worse beta-cell function, in our opinion, this finding may result from improved insulin sensitivity and no further need of beta-cells for adjusting insulin secretion for glucose uptake in target tissues [28]. However, methodological limitations of these fasting indices of beta-cell function should be taken into account given that OGTT was not based on peripheral blood sampling, insulin levels during OGTT were not measured, and the hyperinsulinemic-euglycemic glucose clamp technique was not used.

The present results of the antidiabetic effects of Sclerocarya birrea are consistent with data previously reported in animal studies. In an experimental study, Wistar rats were divided into two groups and treated with a diet of oxidized palm oil and sucrose to induce hyperglycemia or a standard diet for 16 weeks; at the end of this period, animals presenting intolerance in the glucose test and insensitivity to insulin were continuously fed the hypercaloric diet along with the administration of the plant extract of Sclerocarya birrea $(150$ or $300 \mathrm{mg} / \mathrm{kg})$ or glibenclamide $(10 \mathrm{mg} / \mathrm{kg})$ for 3 weeks. The plant extract provoked an inhibition of hyperglycemia during OGTT and a significant increase in the insulin sensitivity index [29]. These results can indicate that the plant extract could act at peripheral levels by several mechanisms, such as reducing glucose absorption from the gastrointestinal tract by inhibition of $\alpha$-glycosidases and $\alpha$-amylases enzymes and/or stimulating peripheral glucose utilization by a mechanism similar to that of chlorpropamide and/or metformin [29]. In another study of streptozotocin-induced diabetes in rats, there was a significant improvement in glucose tolerance in animals treated with Sclerocarya birrea extract and in those treated with metformin (as a reference drug [20]). The effect of Sclerocarya birrea similar to that of metformin could be explained by the presence of some polyphenols in the plant composition, such as epicatechin and epigallocatechin gallate, which have been shown to activate the AMP-activated protein kinase (AMPK) pathway and to inhibit glutamate dehydrogenase (GDH) activity. The hypoglycemic effect of Sclerocarya birrea with better control of insulin secretion and higher insulin sensitivity is still poorly understood, but other glucose-lowering pleiotropic mechanisms in line with sulfonylureas (chlorpropamide) or gallic acid have been suggested, with increased hepatic glycogen synthesis, cytosolic calcium increase with activation of calcium/calmodulin-dependent protein kinase II (CaMKII), activation of the mitogen-activated protein kinases (MAPK) and PI3K/AKT signaling pathways, and increase in glucose transporter GLUT4 [17-21,29,30].

Another interesting finding of the study was an improvement in FMD, which is consistent with a vasorelaxant and hypotensive effect of Sclerocarya birrea observed in endothelium-containing isolated aortic rings from Wistar rats [31]. This was attributed to the formation and release of endothelium-derived nitric oxide (NO) with phosphorylation of NO synthase by the polyphenols present in the plant extract.

In relation to changes in the lipid profile, significant changes in cholesterol, LDL-C, HDL-C, and triglycerides were not observed, although there was a decreasing trend of total cholesterol levels in the experimental group. However, in the study of Ngueguim et al. [29] in rats in which the plant extract was administered together with a standard diet of oxidized 
palm oil and sucrose for 3 weeks, there was a decrease in triglycerides, total cholesterol, LDL-C, and the atherogenic index as compared to controls, suggesting the extract of Sclerocarya birrea may be helpful to the prevention of diabetes complications through a reduction of dyslipidemia. We also observed a decrease of BP in the experimental group, particularly SBP, which is in agreement with a significant reduction of SBP and mean BP reported with the $300 \mathrm{mg} / \mathrm{kg}$ dose of the plant extract in the study of Ngueguim et al. [29]. In a study in normotensive rats, treatment with Sclerocarya birrea leaf extract induced hypotension in a dose-response manner, which was attributed to inhibition of the reninangiotensin-aldosterone system with decreased release of the angiotensin-converting enzyme, combined with induction of the release of endothelium-derived relaxing fact/NO from endothelial cells and activation of guanylate cyclase in arterial smooth muscle and stimulation of cyclic GMP production [32].

In the present study, the use of Sclerocarya birrea for 90 days did not induce changes in anthropometric variables, although there was a decreasing trend in body weight. Data regarding the effect of this plant extract on the body weight and food ingestion of diabeticinduced experimental animals is inconclusive [20,32].

The analysis of inflammatory markers, including serum levels of IL-6 and E-selectin showed a significant decrease of E-selectin levels and a decreasing trend of IL-6 levels in the experimental group, pointing towards an anti-inflammatory effect of Sclerocarya birrea. In a study of the effect of Sclerocarya birrea stem-bark aqueous extract in mice, sustained and significant reductions in the fresh egg albumin-induced acute inflammation of the rat hind paw edema were observed [33]. In another study, the methanol extract of Sclerocarya birrea showed anti-inflammatory activity in carrageenan-, histamine- or serotonin-induced paw edema in rats through a dose-dependent inhibition of inflammatory markers such as tumor necrosis factor alpha (TNF- $\alpha$ ) and IL-6 [34]. The anti-inflammatory effect of Sclerocarya birrea may interplay with the antioxidant activity reducing ROS and advanced glycation end-products [17].

The present findings, however, should be interpreted while taking into account the limitations of the study, including the exploratory nature of the trial, the reduced sample size, and the treatment period of 90 days only. Further studies assessing the use of Sclerocarya birrea in experimental animals and in humans using the hyperinsulinemic-euglycemic glucose clamp technique would contribute to clarifying the underlying mechanisms of the hypoglycemic effect of this natural compound in prediabetes and type 2 diabetes.

\section{Conclusions}

This exploratory clinical trial confirms the antidiabetic activity of a nutraceutical supplement based on a natural extract of Sclerocarya birrea in subjects with confirmed prediabetes, which is a clinically relevant finding in the prevention of type 2 diabetes. Further studies using better measurements of beta-cell function are needed to clarify the underlying mechanisms of the hypoglycemic effect of this natural compound.

Author Contributions: Conceptualization, F.J.L.-R.; data curation, M.S.-M., J.A.G.-H., and F.J.L.-R. formal analysis, F.J.L.-R.; investigation, M.Q.-C., A.J.L.-R., E.B.-M., and M.S.A.-R.; methodology, F.J.L.-R. and J.A.G.-H.; project administration, F.J.L.-R.; resources, D.V.-M., E.B.-M., M.S.-M., A.J.L.-R., V.Á.-G., and J.A.G.-H.; supervision, F.J.L.-R.; visualization, M.S.-M., writing-original draft, D.V.-M. and M.S.-M.; writing-review and editing, E.B.-M., J.A.G.-H., and F.J.L.-R. All authors have read and agreed to the published version of the manuscript.

Funding: This research project has been funded by the Instituto de Fomento de la Región de Murcia through a grant awarded to Herbafor S.L. (2015.08.ID+I.0072).

Institutional Review Board Statement: The study was conducted according to the guidelines of the Declaration of Helsinki and approved by the Ethics Committee of Universidad Católica San Antonio (protocol code 6113, approval date 3 June 2016), Murcia, Spain.

Informed Consent Statement: Written informed consent was obtained from all subjects involved in the study. 
Data Availability Statement: Study data are available from the corresponding author (F.J.L.-R.) upon request.

Acknowledgments: The authors thank Marta Pulido for editing the manuscript and editorial assistance.

Conflicts of Interest: The authors declare no conflict of interest.

\section{References}

1. American Diabetes Association. Prediabetes. Diagnosis. Available online: https://www.diabetes.org/a1c/diagnosis (accessed on 30 April 2021).

2. World Health Organization. Definition and Diagnosis of Diabetes Mellitus and Intermediate Hyperglycemia: Report of a WHO/IDF Consultation; World Health Organization: Geneva, Switzerland, 2006; pp. 1-50.

3. Tabak, A.G.; Herder, C.; Rathmann, W.; Brunner, E.J.; Kivimaki, M. Prediabetes: A high-risk state for diabetes development. Lancet 2012, 379, 2279-2290. [CrossRef]

4. Huang, D.; Refaat, M.; Mohammedi, K.; Jayyousi, A.; Al Suwaidi, J.; Abi Khalil, C. Macrovascular complications in patients with diabetes and prediabetes. Biomed Res. Int. 2017, 2017, 7839101. [CrossRef]

5. Brannick, B.; Wynn, A.; Dagogo-Jack, S. Prediabetes as a toxic environment for the initiation of microvascular and macrovascular complications. Exp. Biol. Med. (Maywood) 2016, 241, 1323-1331. [CrossRef] [PubMed]

6. International Diabetes Federation. IDF Diabetes Atlas. Ninth Edition. 2019. Available online: www.diabetes.atlas.org (accessed on 30 April 2021).

7. Hostalek, U. Global epidemiology of prediabetes-Present and future perspectives. Clin. Diabetes Endocrinol. 2019, 5, 5. [CrossRef] [PubMed]

8. Luc, K.; Schramm-Luc, A.; Guzik, T.J.; Mikolajczyk, T.P. Oxidative stress and inflammatory markers in prediabetes and diabetes. J. Physiol. Pharmacol. 2019, 70, 70. [CrossRef]

9. Alam, F.; Islam, M.A.; Khalil, M.I.; Gan, S.H. Metabolic control of type 2 diabetes by targeting the GLUT4 glucose transporter: Intervention approaches. Curr Pharm Des. 2016, 22, 3034-3049. [CrossRef] [PubMed]

10. Huang, X.; Liu, G.; Guo, J.; Su, Z. The PI3K/AKT pathway in obesity and type 2 diabetes. Int. J. Biol. Sci. 2018, 14, 1483-1496. [CrossRef] [PubMed]

11. Kaneto, H.; Nakatani, Y.; Kawamori, D.; Miyatsuka, T.; Matsuoka, T.A.; Matsuhisa, M.; Yamasaki, Y. Role of oxidative stress, endoplasmic reticulum stress, and c-Jun N-terminal kinase in pancreatic beta-cell dysfunction and insulin resistance. Int. J. Biochem. Cell Biol. 2005, 37, 1595-1608. [CrossRef] [PubMed]

12. Mayans, L. Metabolic syndrome: Insulin resistance and prediabetes. FP Essent. 2015, 435, 11-16. [PubMed]

13. Tuomilehto, J.; Lindström, J.; Eriksson, J.G.; Valle, T.T.; Hämäläinen, H.; Ilanne-Parikka, P.; Keinänen-Kiukaanniemi, S.; Laakso, M.; Louheranta, A.; Rastas, M.; et al. Finnish Diabetes Prevention Study Group. Prevention of type 2 diabetes mellitus by changes in lifestyle among subjects with impaired glucose tolerance. N. Engl. J. Med. 2001, 344, 1343-1350. [CrossRef] [PubMed]

14. Hamman, R.F.; Wing, R.R.; Edelstein, S.L.; Lachin, J.M.; Bray, G.A.; Delahanty, L.; Hoskin, M.; Kriska, A.M.; Mayer-Davis, E.J.; Pi-Sunyer, X.; et al. Effect of weight loss with lifestyle intervention on risk of diabetes. Diabetes Care 2006, 29, $2102-2107$. [CrossRef] [PubMed]

15. Derosa, G.; Limas, C.P.; Macías, P.C.; Estrella, A.; Maffioli, P. Dietary and nutraceutical approach to type 2 diabetes. Arch. Med. Sci. 2014, 10, 336-344. [CrossRef] [PubMed]

16. Onaolapo, A.Y.; Onaolapo, O.J. Nutraceuticals and diet-based phytochemicals in type 2 diabetes mellitus: From whole food to components with defined roles and mechanisms. Curr. Diabetes Rev. 2019, 16, 12-25. [CrossRef] [PubMed]

17. Mariod, A.A.; Abdelwahab, S.I. Sclerocarya birrea (Marula), an African tree of nutritional and medicinal uses: A review. Food Rev. Int. 2012, 28, 375-388. [CrossRef]

18. Mousinho, N.M.; van Tonder, J.J.; Steenkamp, V. In vitro anti-diabetic activity of Sclerocarya birrea and Ziziphus mucronata. Nat. Prod. Commun. 2013, 8, 1279-1284.

19. Ojewole, J.A. Hypoglycemic effect of Sclerocarya birrea [(A. Rich.) Hochst.] [Anacardiaceae] stem-bark aqueous extract in rats. Phytomedicine 2003, 10, 675-681. [CrossRef]

20. Dimo, T.; Rakotonirina, S.V.; Tan, P.V.; Azay, J.; Dongo, E.; Kamtchouing, P.; Cros, G. Effect of Sclerocarya birrea (Anacardiaceae) stem bark methylene chloride/methanol extract on streptozotocin-diabetic rats. J. Ethnopharmacol. 2007, 110, 434-438. [CrossRef]

21. Gondwe, M.; Kamadyaapa, D.R.; Tufts, M.; Chuturgoon, A.A.; Musabayane, C.T. Sclerocarya birrea [(A. Rich.) Hochst.] [Anacardiaceae] stem-bark ethanolic extract (SBE) modulates blood glucose, glomerular filtration rate (GFR) and mean arterial blood pressure (MAP) of STZ-induced diabetic rats. Phytomedicine 2008, 15, 699-709. [CrossRef] [PubMed]

22. Tsabang, N.; Ngah, N.; Estella, F.T.; Agbor, G.A. Herbal Medicine and Treatment of Diabetes in Africa: Case Study in Cameroon. Diabetes Case Reports 2017, 1, 1000112. [CrossRef]

23. Jiménez-Sánchez, C.; Lozano-Sánchez, J.; Gabaldón-Hernández, J.A.; Segura-Carretero, A.; Fernández-Gutiérrez, A. RP-HPLCESI-QTOF/MS2 based strategy for the comprehensive metabolite profiling of Sclerocarya birrea (marula) bark. Ind. Crops Prod. 2015, 71, 214-234. [CrossRef] 
24. Williams, B.; Mancia, G.; Spiering, W.; Agabiti Rosei, E.; Azizi, M.; Burnier, M.; Clement, D.L.; Coca, A.; de Simone, G.; Dominiczak, A.; et al. ESC Scientific Document Group. 2018 ESC/ESH Guidelines for the management of arterial hypertension. Eur. Heart J. 2018, 39, 3021-3104. [CrossRef] [PubMed]

25. Corretti, M.C.; Anderson, T.J.; Benjamin, E.J.; Celermajer, D.; Charbonneau, F.; Creager, M.A.; Deanfield, J.; Drexler, H.; GerhardHerman, M.; Herrington, D.; et al. International Brachial Artery Reactivity Task Force. Guidelines for the ultrasound assessment of endothelial-dependent flow-mediated vasodilation of the brachial artery: A report of the International Brachial Artery Reactivity Task Force. J. Am. Coll. Cardiol. 2002, 39, 257-265. [CrossRef]

26. Armstrong, F.; Bull, F. Development of the World Health Organization Global Physical Activity Questionnaire (GPAQ). J. Public Health 2006, 14, 66-70. [CrossRef]

27. Ahn, H.Y.; Kim, M.; Seo, C.R.; Yoo, H.J.; Lee, S.H.; Lee, J.H. The effects of Jerusalem artichoke and fermented soybean powder mixture supplementation on blood glucose and oxidative stress in subjects with prediabetes or newly diagnosed type 2 diabetes. Nutr. Diabetes 2018, 8, 42. [CrossRef] [PubMed]

28. Movahed, A.; Raj, P.; Nabipour, I.; Mahmoodi, M.; Ostovar, A.; Kalantarhormozi, M.; Netticadan, T. Efficacy and Safety of Resveratrol in Type 1 Diabetes Patients: A Two-Month Preliminary Exploratory Trial. Nutrients 2020, 12, 161. [CrossRef] [PubMed]

29. Ngueguim, F.T.; Esse, E.C.; Dzeufiet, P.D.; Gounoue, R.K.; Bilanda, D.C.; Kamtchouing, P.; Dimo, T. Oxidised palm oil and sucrose induced hyperglycemia in normal rats: Effects of Sclerocarya birrea stem barks aqueous extract. BMC Complement. Altern. Med. 2016, 16, 47. [CrossRef]

30. Makom Ndifossap, I.G.; Frigerio, F.; Casimir, M.; Ngueguim Tsofack, F.; Dongo, E.; Kamtchouing, P.; Dimo, T.; Maechler, P. Sclerocarya birrea (Anacardiaceae) stem-bark extract corrects glycaemia in diabetic rats and acts on beta-cells by enhancing glucose-stimulated insulin secretion. J. Endocrinol. 2010, 205, 79-86. [CrossRef] [PubMed]

31. Ojewole, J.A. Vasorelaxant and hypotensive effects of Sclerocarya birrea (A Rich) Hochst (Anacardiaceae) stem bark aqueous extract in rats. Cardiovasc. J. South Afr. 2006, 17, 117-123.

32. Belemtougri, R.G.; Dzamitika, S.A.; Oudraogo, Y.; Sawadogo, L. Effects of water crude leaf extract of Sclerocarya birrea (A. Rich) Hochts (Anacardiacea) on normotensive rat blood pressure. J. Biol. Sci. 2007, 7, 570-574. [CrossRef]

33. Ojewole, J.A. Evaluation of the analgesic, anti-inflammatory and anti-diabetic properties of Sclerocarya birrea (A. Rich.) Hochst. stem-bark aqueous extract in mice and rats. Phytother. Res. 2004, 18, 601-608. [CrossRef]

34. Fotio, A.L.; Dimo, T.; Nguelefack, T.B.; Dzeufiet, P.D.; Ngo Lemba, E.; Temdie, R.J.; Ngueguim, F.; Olleros, M.L.; Vesin, D.; Dongo, E.; et al. Acute and chronic anti-inflammatory properties of the stem bark aqueous and methanol extracts of Sclerocarya birrea (Anacardiaceae). Inflammopharmacology 2009, 17, 229-237. [CrossRef] [PubMed] 